\title{
Detection of Virulence to Resistance Gene Sr24 Within Race TTKS of Puccinia graminis f. sp. tritici
}

\author{
Y. Jin and L. J. Szabo, United States Department of Agriculture-Agricultural Research Service, Cereal Disease \\ Laboratory, University of Minnesota, St. Paul 55108; Z. A. Pretorius, Department of Plant Sciences, University of \\ the Free State, Bloemfontein 9300, South Africa; R. P. Singh and R. Ward, International Maize and Wheat Im- \\ provement Center (CIMMYT), Apdo, Postal 6-641, Mexico D.F., Mexico; and T. Fetch, Jr., Cereal Research Centre, \\ Agriculture and Agri-Food Canada, Winnipeg, MB, R3T 2M9, Canada
}

\begin{abstract}
Jin, Y., Szabo, L. J., Pretorius, Z. A., Singh, R. P., Ward, R., and Fetch, T., Jr. 2008. Detection of virulence to resistance gene $S r 24$ within race TTKS of Puccinia graminis f. sp. tritici. Plant Dis. 92:923-926.

The stem rust resistance gene $\mathrm{Sr} 24$ is effective against most races of Puccinia graminis f. sp. tritici, including race TTKS (syn. Ug99), and is used widely in commercial wheat cultivars worldwide. In 2006, susceptible infection responses were observed on wheat lines and cultivars carrying $\mathrm{Sr} 24$ in a field stem rust screening nursery at Njoro, Kenya. We derived 28 singlepustule isolates from stem rust samples collected from the 2006 Njoro nursery. The isolates were evaluated for virulence on 16 North American stem rust differential lines; on wheat lines carrying $\operatorname{Sr} 24, \operatorname{Sr} 31, \operatorname{Sr} 38$, and $\operatorname{SrMcN}$; and on a wheat cultivar with a combination of $\operatorname{Sr} 24$ and $\operatorname{Sr} 31$. All isolates were identified as race TTKS with additional virulence on $\operatorname{Sr} 31$ and $\operatorname{Sr} 38$. These isolates were divided into two groups: group A (seven isolates and the two control isolates), producing a low infection type, and group B (21 isolates), producing a high infection type on $S r 24$, respectively. Isolates of group B represented a new variant of race TTKS with virulence to Sr24. Eighteen simple sequence repeat (SSR) markers were used to examine the genetic relationship between these two groups of isolates in race TTKS and five North American races (MCCF, QCCQ, RCRS, RTHS, and TPMK) that are representative of distinct lineage groups. All isolates of race TTKS shared an identical SSR genotype and were clearly different from North American races. The virulence and SSR data indicated that the new variant of race TTKS with $S r 24$ virulence likely has arisen via mutation within the TTKS genetic lineage. We propose to revise the North American stem rust nomenclature system by the addition of four genes $(\operatorname{Sr} 24$, $\mathrm{Sr} 31, \mathrm{Sr} 38$, and $\mathrm{SrMcN}$ ) as the fifth set. This revision recognizes the virulence on $\operatorname{Sr} 31$ and differentiates isolates within race TTKS into two separate races: TTKSK and TTKST, with avirulence and virulence on $S r 24$, respectively. The occurrence of race TTKST with combined virulence on $\operatorname{Sr} 24$ and $\mathrm{Sr} 31$ has substantially increased the vulnerability of wheat to stem rust worldwide.
\end{abstract}

Stem rust, caused by Puccinia graminis f. sp. tritici, is one of the most destructive diseases of wheat (Triticum aestivum and T. turgidum subsp. durum) and barley (Hordeum vulgare). In many wheat pro-

Corresponding author: Y. Jin

E-mail: yuejin@umn.edu

Mention of a trademark, vendor, or proprietary product does not constitute a guarantee or warranty of the product by the United States Department of Agriculture (USDA) and does not imply its approval to the exclusion of other product or vendors that also may be suitable.

USDA-Agricultural Research Service Cereal Disease Laboratory maintains seed stocks used in this study and they are available upon request from the corresponding author.

Accepted for publication 7 February 2008.

doi:10.1094/PDIS-92-6-0923

This article is in the public domain and not copyrightable. It may be freely reprinted with customary crediting of the source. The American Phytopathological Society, 2008. duction areas, the disease has been controlled effectively through the widespread use of host resistance. The gene Sr24, originally transferred from Elytrigia elongata to bread wheat (16), is a valuable source of resistance, effective against most stem rust races worldwide, although stem rust races with $\mathrm{Sr} 24$ virulence have been detected in South Africa (7) and India (2). $\mathrm{Sr} 24$ has been deployed in wheat cultivars in Australia, South Africa, and North and South America partly because of the effectiveness against a broad spectrum of stem rust races and partly because of its close linkage with $L r 24$, a gene conferring resistance to leaf rust (8). $\mathrm{Sr} 24$ is highly effective against race TTKS (or Ug99) (5), a recently emerged race with virulence to Sr31 that is considered to be a serious threat to wheat production worldwide $(10,15,19)$. Results from the 2005 and 2006 stem rust field screening in Kenya and seedling studies in the United States suggested that $\mathrm{Sr} 24$ is a major component for TTKS resistance in adapted germplasm. Based on stem rust ratings on the monogenic resistant line LcSr24Ag as well as from observations on breeding lines and cultivars known to carry this gene, $\mathrm{Sr} 24$ was highly effective in the stem rust screening nursery at Njoro, Kenya in 2005 where race TTKS was predominant (6). Infection responses were resistant to moderately resistant, with terminal stem rust severity up to $20 \%$. However, in the 2006 stem rust field screening nursery at Njoro, we observed a low frequency of uredinia (pustules) with infection responses of moderately susceptible to susceptible types on the two monogenic lines for Sr24, LcSr24Ag, and Agent/9*LMPG, and many breeding lines and cultivars carrying $\mathrm{Sr} 24$, suggesting that virulence on $\mathrm{Sr} 24$ was present in the nursery. The objective of this study was to determine variation in virulence and genetic relationships among isolates of race TTKS.

\section{MATERIALS AND METHODS}

Sample collection and storage. Samples were collected in September 2006 from wheat lines and cultivars known or suspected to carry $\mathrm{Sr} 24$ or $\mathrm{Sr} 31$ in a stem rust nursery $\left(0^{\circ} 20^{\prime} \mathrm{S}, 35^{\circ} 56^{\prime} \mathrm{E}\right)$ in Njoro, Kenya. Leaf sheath tissue bearing moderately susceptible or susceptible pustules were cut into pieces of 2 to $3 \mathrm{~cm}$ in length, with true stem tissue and nodes removed to facilitate the drying process. Each sample consisted of three to five pieces of tissue collected from the same line within a plot. Samples were placed in glassine bags and air dried for 3 to 4 days at room temperature. A subset of samples was vacuum dried. Dried samples were mailed using an express mail service with a transit time of 14 days from the date of mailing to the date of arrival at the destination. Upon receipt, the samples were placed immediately in a $-80^{\circ} \mathrm{C}$ freezer and were stored for approximately 3 months. In all, 11 field samples collected from nine cultivars or lines in the Njoro nursery were processed in the study: 1 sample from an unknown line, 1 from a line carrying $S r 31$, and the remaining 9 samples from lines suspected to carry $\operatorname{Sr} 24$. Samples stored in glassine bags were repackaged into ziplock bags after removal from the storage freezer and submersed in a water bath at $43^{\circ} \mathrm{C}$ for 15 min. After the heat-shock treatment, urediniospores from each sample were col- 
lected into a gelatin capsule (size 00) using a small cyclone collector and placed in a rehydration chamber for 2 to $4 \mathrm{~h}$, where approximately $80 \%$ relative humidity was maintained by a $\mathrm{KOH}$ solution (14). Approximately $0.5 \mathrm{ml}$ of a light mineral oil (Soltrol 170) was added into each gelatin capsule to suspend urediniospores for subsequent inoculation of differential lines.

Differential lines. In addition to the 16 differentials in the $P$. graminis f. sp. tritici differential set of North America $(11,12)$, we included 7 supplemental tester lines: LcSr24Ag and Agent/9*LMPG (monogenic lines for $S r 24$ ), Ivan (a hard red spring wheat cultivar carrying Sr24), Benno Sr31/6*LMPG (monogenic line for Sr31), VPM 1 (PI 519303, a tester stock for $S r 38$ ), McNair 701 (CI 15288, a winter wheat cultivar carrying $\mathrm{SrMcN}$ ), and Siouxland (PI 483469, a winter wheat cultivar carrying Sr24 and Sr31). Four lines were planted in each corner of a square pot $(5$ by $5 \mathrm{~cm}$ ) containing vermiculite. Six pots planted with 16 differential lines and 7 supplemental lines were placed in a custom-made plastic tray with each pot in a fixed position. After planting, trays were placed in a greenhouse designated for raising clean plants. Plants were fertilized using a solution of water-soluble fertilizer three times: immediately after plant emergence, after removal from the mist chamber, and 7 days after inoculation.
Inoculation, incubation, and disease assessment. Seedling plants of the 23 lines in each tray were inoculated with a bulk collection of spores from each sample when the primary leaves were fully expanded ( 7 to 9 days after planting). A petri plate containing water agar (20 $\mathrm{g}$ of Difco agar in 1.0 liter of $\mathrm{H}_{2} \mathrm{O}$ ) also was sprayed with the inoculum and examined $4 \mathrm{~h}$ later under a microscope to determine the percentage of spore germination. Seedlings were incubated in a dew chamber for $14 \mathrm{~h}$ at $18^{\circ} \mathrm{C}$ in the dark, and then for an additional period of 3 to $4 \mathrm{~h}$ under fluorescent light. The inoculated plants were placed on a greenhouse bench at $18 \pm 2^{\circ} \mathrm{C}$ with a photoperiod of $16 \mathrm{~h}$. Infection types (ITs), described by Stakman et al. (17), were assessed 14 days post-inoculation. ITs 0 , ; 1,2 , or combinations thereof were considered low ITs, indicating that the corresponding resistance gene was effective. ITs 3 to 4 were considered high ITs, indicating that the corresponding resistance gene was not effective against the isolate tested.

Derivation of single-pustule cultures. Because the primary purpose of this study was to identify isolates with virulence on $S r 24$, we focused on isolating from pustules on $\mathrm{Sr} 24$ lines with ITs higher than 2. Single-pustule isolation on lines with other genes also was made in an attempt to obtain races in addition to those with virulence on $\mathrm{Sr} 24$. After preliminary scoring of the differential and supplemental lines, a leaf suitable for single-pustule isolation (i.e., pustules were well spaced) was selected and remaining plants were removed from the pot. The leaf was trimmed to remove other pustules if more than one pustule was present. The seedling with the single pustule was incubated in a mist chamber overnight to germinate any contaminant spores, followed by incubation in an isolation cubicle in a greenhouse. The new crop of urediniospores produced from the single pustule was collected by scraping the spores directly into a gelatin capsule 1 or 2 days after mist incubation, and collection continued for a period of 3 days. The spores collected from a single pustule were used to directly inoculate a differential set. The culture derived from the single-pustule isolation procedure was considered a pure culture, subsequently increased on a susceptible line (McNair 701 ), and stored in a $-80^{\circ} \mathrm{C}$ freezer or liquid nitrogen for future use. Each single-pustulederived isolate was evaluated for virulence on the differential and supplemental lines twice. Two isolates of race TTKS, isolate 98UGA-1-1 collected from Uganda in 1999 (10) and isolate 04KEN156/04 collected from Kenya in 2004 (19), were evaluated on the differential and supplemental lines to compare their virulence pattern with the isolates derived from the 2006 collections from Njoro, Kenya.

Table 1. Infection types produced on $\mathrm{Sr} 24$ lines and other supplemental differentials by isolates derived from stem rust samples collected from the 2006 stem rust nursery planted at Njoro, Kenya ${ }^{a}$

\begin{tabular}{|c|c|c|c|c|c|c|c|}
\hline Isolate & $\begin{array}{l}\text { Single pustule } \\
\text { derived from }\end{array}$ & $\begin{array}{l}\text { LcSr24Ag } \\
\text { (Sr24) }\end{array}$ & $\begin{array}{c}\text { Agent/9*LMPG } \\
(\text { Sr24) }\end{array}$ & $\begin{array}{l}\text { Ivan } \\
(\text { Sr24) }\end{array}$ & $\begin{array}{c}\text { Sr31/6*LMPG } \\
(\text { Sr31 })\end{array}$ & $\begin{array}{c}\text { Siouxland } \\
(\operatorname{Sr} 24+S r 31)\end{array}$ & $\begin{array}{l}\text { Virulence } \\
\text { group }\end{array}$ \\
\hline 98UGA-1-1 ${ }^{\mathrm{b}}$ & TTKS check culture & 2 & $2-$ & $2-$ & $3+$ & 2 & $\mathrm{~A}$ \\
\hline 04KEN156/04 & TTKS check culture & 2 & $2-$ & $2-$ & $3+$ & 2 & A \\
\hline 06KEN03-1 & McNair 701 & 2 & $1+$ & $2-$ & $3+$ & 2 & A \\
\hline 06 KEN10-1 $1^{\mathrm{b}}$ & ISr5-Ra & 2 & $2-$ & 2 & $3+$ & 2 & A \\
\hline 06KEN10-2 & CnsTmono-deri. & 2 & $2-$ & 2 & 3 & 2 & A \\
\hline 06KEN10-3 ${ }^{\mathrm{b}}$ & W2691Sr9b & 2 & $2-$ & 2 & 4 & 2 & A \\
\hline 06KEN13-1 & McNair 701 & 2 & 1 & $2-$ & $3+$ & $2-$ & A \\
\hline 06KEN16-2 $2^{\mathrm{b}}$ & Benno Sr31/6*LMPG & 2 & $1-$ & $2-$ & 4 & 1 & A \\
\hline 06KEN22-4 & McNair 701 & 2 & $2-$ & 2 & 4 & 2 & A \\
\hline 06KEN16-1 $1^{\mathrm{b}}$ & $\mathrm{LcSr} 24 \mathrm{Ag}$ & $3+$ & 3 & 3 & $3+$ & 3 & B \\
\hline 06KEN16-3 & BtSr30Wst & $3+$ & 3 & 3 & 4 & 3 & $\mathrm{~B}$ \\
\hline 06KEN16-V-1 ${ }^{\mathrm{b}}$ & Benno Sr31/6*LMPG & 3 & 3 & 3 & 4 & 3 & B \\
\hline 06KEN16-V-2 ${ }^{\mathrm{b}}$ & Siouxland & 3 & $3-$ & 3 & $3+$ & 3 & B \\
\hline 06KEN16-V-3 ${ }^{\mathrm{b}}$ & ISr6-Ra & $3+$ & 3 & 3 & 4 & 3 & B \\
\hline 06KEN17-3 & W2691Sr9b & 3 & 3 & 3 & 4 & $3+$ & B \\
\hline 06KEN19-1 $1^{\mathrm{b}}$ & $\mathrm{LcSr} 24 \mathrm{Ag}$ & 3 & $3-$ & $2++$ & $3+$ & 3 & B \\
\hline 06KEN19-2 $2^{\mathrm{b}}$ & Bt/Wld & $3+$ & 3 & 3 & 4 & 3 & B \\
\hline 06 KEN19-3 ${ }^{\mathrm{b}}$ & McNair 701 & 3 & 3 & 3 & $3+$ & $3-$ & $\mathrm{B}$ \\
\hline 06KEN19-V-2 $2^{b}$ & Agent/9*LMPG & $3-$ & 3 & $3-$ & $3+$ & $3+$ & B \\
\hline 06 KEN19-V-3 ${ }^{b}$ & $\mathrm{LcSr} 24 \mathrm{Ag}$ & 3 & 3 & 3 & 3 & 3 & $\mathrm{~B}$ \\
\hline 06KEN19-V-4 & Combination VII & $3+$ & 3 & $3-$ & 4 & $3-$ & B \\
\hline 06KEN19-V-5 ${ }^{\mathrm{b}}$ & Benno Sr31/6*LMPG & 3 & 3 & 3 & 4 & 3 & B \\
\hline $06 \mathrm{KEN} 20-\mathrm{V}-1^{\mathrm{b}}$ & Ivan & 3 & 3 & 3 & 4 & $3+$ & $\mathrm{B}$ \\
\hline 06KEN20-V-2 ${ }^{\mathrm{b}}$ & $\mathrm{LcSr} 24 \mathrm{Ag}$ & 3 & 3 & 3 & 4 & 3 & B \\
\hline 06KEN20-V-4 ${ }^{\mathrm{b}}$ & Benno Sr31/6*LMPG & $3-$ & 3 & 3 & 4 & 3 & $\mathrm{~B}$ \\
\hline $06 \mathrm{KEN} 20-\mathrm{V}-5^{\mathrm{b}}$ & Bt/Wld & 3 & 3 & $3-$ & $3+$ & 3 & B \\
\hline 06KEN20-V-6 ${ }^{\mathrm{b}}$ & ISr6-Ra & 3 & $3-$ & $3-$ & 4 & 3 & B \\
\hline 06KEN23-1 & Ivan & $33-$ & 3 & $3-$ & 3 & 3 & B \\
\hline 06KEN23-2 $2^{\mathrm{b}}$ & Stoa & $3-$ & 3 & 3 & 3 & $3-$ & B \\
\hline 06KEN19-V-6 & Benno Sr31/6*LMPG & 3 & 3 & 3 & 4 & $3+$ & B \\
\hline
\end{tabular}

${ }^{a}$ Infection types (ITs) at the seedling stage following the descriptions of Stakman et al. (16), where ITs $0, ;, 1,2$, or combinations thereof were considered low ITs, and ITs 3 to 4 were considered high ITs.

${ }^{\mathrm{b}}$ Isolates included in the simple sequence repeat analysis. 
Determination of simple sequence repeat genotypes. DNA was extracted from either urediniospores or infected wheat leaf tissue using an OmniPrep DNA extraction kit (GenoTech, St. Louis) as described by Anikster et al. (1). Polymerase chain reaction (PCR) amplification conditions of simple sequence repeat (SSR) loci and detection of alleles were as described previously (18). SSR primers used were PgtSSR3, PgtSSR4, PgtSSR6, PgtSSR11, PgtSSR12， PgtSSR14， PgtSSR20, PgtSSR21, PgtSSR47, PgtSSR68, PgtSSR90, PgtSSR129, PgtSSR134, PgtSSR140, PgtSSR147, PgtSSR151, PgtSSR162, and PgtSSR164 (18). In all, 36 isolates were used in the SSR analysis, which included 13 isolates of race TTKS avirulent on Sr24 (Table 1 and 04KEN152/ 02, 04KEN153/02, 04KEN155/04, 04KEN157/04, 04KEN158/04, 04KEN159/ 04, 04KEN160/04, and 04KEN161/04), 18 isolates of race TTKS virulent on $\mathrm{Sr} 24$ (Table 1), and 5 standard U.S. isolates (74MN1409, race TPMK; 96MN83a-3, race RTHS; 77ND82-a, race RCRS; 03LA94c, race QCCQ; and 03ND110a, race MCCF). GENALEX 6 (9) was used for principal coordinate analysis of the SSR data.

\section{RESULTS AND DISCUSSION}

In total, 28 single-pustule-derived isolates of $P$. graminis f. sp. tritici from the 2006 Njoro collections were used in this study (Table 1). When tested against the 16 single-gene differential lines of the North American stem rust nomenclature system $(11,12)$, all isolates produced a nearimmunity reaction (IT 0 to 0 ;) on line W2691SrTt-1 carrying resistance gene Sr36 and a low IT (2+) on line CnsSrTmp carrying resistance gene SrTmp, but high (or susceptible) ITs (3 to 4) on all other differential lines except for line Combination VII $(S r 13+S r 17$; Table 2). The IT (2+ to $2++$ ) produced on Combination VII was due to the effect of $\mathrm{Srl} 3$ at a relatively low incubation temperature $\left(18^{\circ} \mathrm{C}\right)$. However, it is considered a high IT for the intended differential gene $\operatorname{Sr} 17$ because, when a race is avirulent on $\mathrm{Sr} 17$, the expected low IT is from ; to ;1 $(8,13)$. All 28 isolates derived from the 2006 Njoro collections produced a virulence-avirulence pattern on the 16 differential lines identical to that of TTKS control isolates 98UGA-1-1 and 04KEN156/04.

On the seven supplemental wheat lines containing resistance genes $\mathrm{Sr} 24, \mathrm{Sr} 31$, $\mathrm{Sr} 38, \mathrm{SrMcN}$, and a combination of $\mathrm{Sr} 24$ and $S r 31$, all isolates produced a high IT (3 to 4) on lines carrying genes $\mathrm{Sr} 31, \mathrm{Sr} 38$, and $\operatorname{SrMcN}$ (Tables 1 and 2). The isolates were differentiated into two groups based on their reactions to resistance gene $\operatorname{Sr} 24$ : group A consisted of 9 isolates (including two control isolates) producing a low IT (1+ to 2) on $S r 24$ lines and group B consisted of 21 isolates producing a relatively high IT (3- to 3+) on lines carrying $\mathrm{Sr} 24$ as well as on cv. Siouxland $(\operatorname{Sr} 24+S r 31)$. The isolates in group A produced low ITs typical of what is expected on $\mathrm{Sr} 24$ when challenged by an avirulent race, and were similar to isolates reported previously from Uganda (10) and Kenya (19) with avirulence on $\mathrm{Sr} 24$ (6). Although we did not observe a fully compatible reaction (IT 4) by group B isolates on lines with $\mathrm{Sr} 24$, the observed ITs (3- to $3+$ ) were sufficiently high and considered compatible on $\mathrm{Sr} 24$. This group of isolates likely represents a new variant within race TTKS that produced susceptible infection responses on Sr24 lines in the 2006 field stem rust nursery at Njoro.

The group B isolates with virulence on $\mathrm{Sr} 24$ were distinctly different from the Sr24-virulent race detected in South Africa in the 1980s. The stem rust culture UVPgt52, isolated from race 2 SA100 described by Le Roux and Rijkenberg (7), was identified as race LKCS (Y. Jin and Z. Pretorius, unpublished data). Compared with the original description, the LKCS phenotype differed on $\operatorname{Sr} 7 b, \operatorname{Sr} 9 b$, and Sr11. These differences could be ascribed to different tester lines in the respective differential sets and interpretation of intermediate ITs. However, LKCS differs from TTKS with respect to several other avirulence genes, including $\mathrm{Sr} 21, \mathrm{Sr} 30$, Sr31, and Sr38, suggesting that these races developed separately.

Eighteen SSR markers (18) were used to examine the genetic relationship between
31 selected isolates of the TTKS race cluster, including reference isolate $98 \mathrm{UGA} 1-1$, 9 Kenyan isolates collected in 2004, and 21 Kenyan isolates collected in 2006. This set included 13 isolates that are avirulent on $\mathrm{Sr} 24$ and 18 that are virulent on $\mathrm{Sr} 24$. In addition, five standard U.S. isolates were included. Sixty-five alleles were scored for the 18 SSR loci examined, indicating that these loci are polymorphic for this set of isolates (data not shown). All 31 isolates of the TTKS race cluster had an identical SSR genotype and were distinct from the five U.S. isolates (Fig. 1). These results confirm the avirulence and virulence phenotype data, indicating that the collections of race TTKS from Kenya in 2004 and 2006 are of the same genetic lineage as the original collection (98UGA1-1) made in Uganda in 1998. Each of the 18 isolates with virulence on Sr24 (group B) had identical SSR genotypes compared with the isolates avirulent on $\operatorname{Sr} 24$ (group A), indicating that the new variant of race TTKS with $\mathrm{Sr} 24$ virulence has arisen via mutation within the TTKS genetic lineage rather than representing a separate genetic lineage. Additional DNA markers will need to be developed to differentiate between these two subgroups of race TTKS.

The unique virulence on $\mathrm{Sr} 31$ as well as variations within race TTKS cannot be recognized based on the current 16 differential lines used in the North American stem rust nomenclature system. We pro-

Table 2. Infection types produced by the two groups of Puccinia graminis f. sp. tritici TTKS isolates on the revised North American set of differential lines and their new race designations ${ }^{\mathrm{a}}$

\begin{tabular}{|c|c|c|c|c|}
\hline Set, line ${ }^{b}$ & Accession no. & Sr gene & Group $\mathrm{A}$ isolates & Group B isolates \\
\hline \multicolumn{5}{|l|}{ I } \\
\hline ISr5-Ra & CI 14159 & 5 & 4 & 4 \\
\hline Cns_T_mono_deriv & & 21 & $3+$ & 4 \\
\hline Vernstein & PI 442914 & $9 e$ & 4 & 4 \\
\hline ISr7b-Ra & CI 14165 & $7 b$ & $3+$ & 4 \\
\hline \multicolumn{5}{|l|}{ II } \\
\hline ISr11-Ra & CI 14171 & 11 & $3+$ & 4 \\
\hline ISr6-Ra & CI 14163 & 6 & 4 & 4 \\
\hline ISr8-Ra & CI 14167 & $8 a$ & 4 & 4 \\
\hline $\mathrm{CnSr} 9 \mathrm{~g}$ & $\ldots$ & $9 g$ & 4 & 4 \\
\hline \multicolumn{5}{|l|}{ III } \\
\hline W2691SrTt-1 & CI 17385 & 36 & 0 & 0 \\
\hline W2691Sr9b & CI 17386 & $9 b$ & 4 & 4 \\
\hline BtSr30Wst & PI 442897 & 30 & 4 & 4 \\
\hline Combination VII & PI 520262 & $13+17$ & $2++^{c}$ & $2++^{c}$ \\
\hline \multicolumn{5}{|l|}{ IV } \\
\hline ISr9a-Ra & CI 14169 & $9 a$ & 4 & 4 \\
\hline ISr9d-Ra & CI 14177 & $9 d$ & 4 & 4 \\
\hline W2691Sr10 & CI 17388 & 10 & 4 & 4 \\
\hline CnsSrTmp & $\ldots$ & $T m p$ & $2+$ & $2++$ \\
\hline \multicolumn{5}{|l|}{$\mathrm{V}$} \\
\hline $\mathrm{LcSr} 24 \mathrm{Ag}$ & $\ldots$ & 24 & 2 & $3+$ \\
\hline Benno Sr31/6*LMPG & $\ldots$ & 31 & $3+$ & 4 \\
\hline VPM 1 & PI 519303 & 38 & 4 & 4 \\
\hline McNair 701 & CI 15288 & $M c N$ & 4 & 4 \\
\hline Race designation & $\ldots$ & $\ldots$ & TTKSK & TTKST \\
\hline
\end{tabular}

${ }^{a}$ Infection types (ITs) at the seedling stage following the descriptions of Stakman et al. (16), where ITs $0, ;, 1,2$, or combinations thereof were considered low ITs, and ITs 3 to 4 were considered high ITs

${ }^{\mathrm{b}}$ Differential sets I to IV are described in Roelfs and Martens (12) and Roelfs et al. (11).

${ }^{\mathrm{c}}$ IT $2++$ produced on combination VII was due to the effect of $\mathrm{Sr} 13$ at a relatively low incubation temperature $\left(18^{\circ} \mathrm{C}\right)$. However, it is considered a high IT for the intended differential gene $\mathrm{Sr} 17$ because, when a race is avirulent on $\operatorname{Sr} 17$, the expected low IT is from ; to $; 1(8,13)$. 


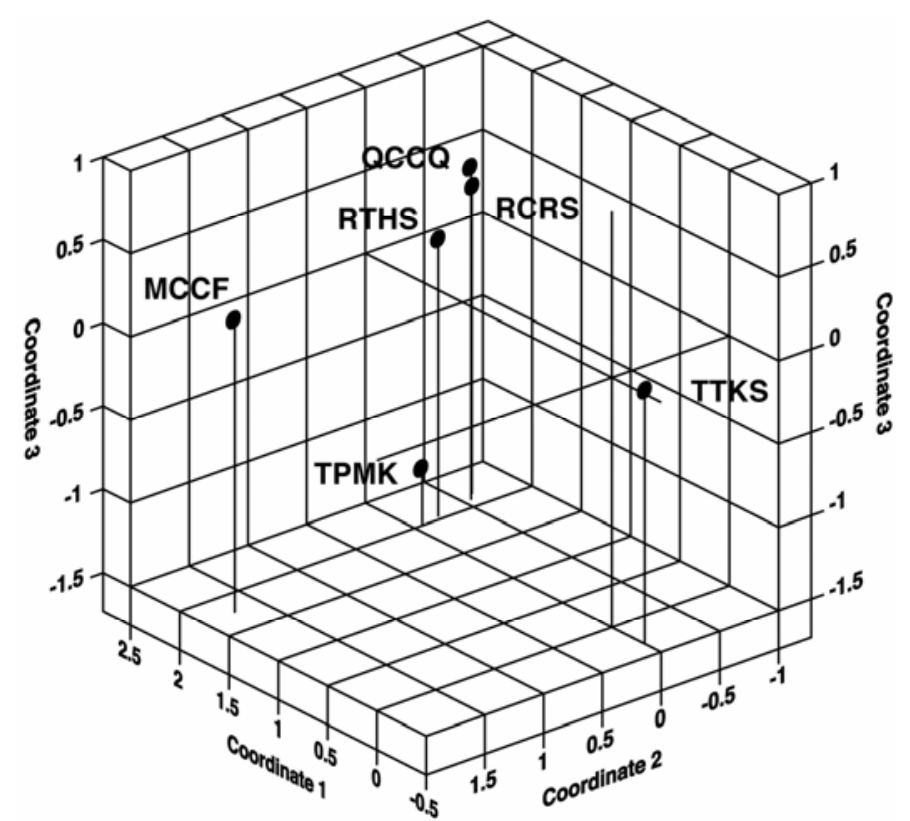

Fig. 1. Plot of principal coordinate analysis of Puccinia graminis f. sp. tritici isolates based on simple sequence repeat data. In all, 31 Kenyan isolates of race TTKS were analyzed, including 13 avirulent on $\mathrm{Sr} 24$ (group A) and 18 virulent on Sr24 (group B). Five common North American races (one isolate of each race) were included for reference. The first three eigenvectors (coordinates) explained $93 \%$ of the variation.

pose to revise this nomenclature system by the addition of four genes, $\operatorname{Sr} 24, \operatorname{Sr} 31$, $\mathrm{Sr} 38$, and $\operatorname{SrMcN}$, as the fifth set. These genes are important in wheat breeding. This revision recognizes the new virulence on $\mathrm{Sr} 31$ and differentiates isolates within race TTKS into two separate races: TTKSK and TTKST, with avirulence and virulence, respectively, on $\operatorname{Sr} 24$. With a few exceptions, races virulent on $\mathrm{Sr} 24$, $S r 31$, or $S r 38$ are rare in the stem rust population in North America as well as worldwide. Although races virulent on $\mathrm{SrMcN}$ are common in the North American stem rust population, the gene is very useful in distinguishing isolates frequently occurring on barley from those occurring on wheat, as well as isolates from the alternate host. McNair $701(\mathrm{SrMcN})$ has been used as a supplemental differential in Canadian race surveys $(3,4)$.

The emergence of virulence on $\mathrm{Sr} 24$ within the TTKS race cluster likely has increased the vulnerability of wheat to stem rust worldwide because of the widespread use of this gene in breeding. Commercial cultivars with resistance based on $\mathrm{Sr} 24$ and/or Sr31, particularly in the East African region, must be viewed with cir-
Plant Pathol. 19:171-175.

5. Jin, Y., and Singh, R. 2006. Resistance to recent eastern African stem rust isolates with virulence to $\mathrm{Sr} 31$ in U.S. wheat. Plant Dis. 90:476-480.

6. Jin, Y., Singh, R. P., Ward, R. W., Wanyera, R., Kinyua, M. G., Njau, P., Fetch, T., Jr., Pretorius, Z. A., and Yahyaoui, A. 2007. Characterization of seedling infection types and adult plant infection responses of monogenic $\mathrm{Sr}$ gene lines to race TTKS of Puccinia graminis f. sp. tritici. Plant Dis. 91:1096-1099.

7. Le Roux, J., and Rijkenberg, F. H. J. 1987. Pathotypes of Puccinia graminis f. sp. tritici with increased virulence for Sr24. Plant Dis. 71:1115-1119.

8. McIntosh, R. A., Wellings, C. R., and Park, R. F. 1995. Wheat Rusts: An Atlas of Resistance Genes. CSIRO, Australia.

9. Peakall, R., and Smouse, P. E. 2006 GENALEX 6: genetic analysis in Excel. Population genetic software for teaching and research. Mol. Ecol. Notes 6:288-295.

10. Pretorius, Z. A., Singh, R. P., Wagoire, W. W., and Payne, T. S. 2000. Detection of virulence to wheat stem rust resistance gene $\mathrm{Sr} 31$ in Puccinia graminis f. sp. tritici in Uganda. Plant Dis. 84:203.

11. Roelfs, A. P., Long, D. L., and Roberts, J. J. 1993. Races of Puccinia graminis in the United States during 1990. Plant Dis. 77:125128.

12. Roelfs, A. P., and Martens, J. W. 1988. An international system of nomenclature for $\mathrm{Puc}$ cinia graminis f. sp. tritici. Phytopathology 78:526-533.

13. Roelfs, A. P., and McVey, D. V. 1979. Low infection types produced by Puccinia graminis $\mathrm{f}$. sp. tritici and wheat lines with designated genes for resistance. Phytopathology 69:722-730.

14. Rowell, J. B. 1984. Controlled infection by Puccinia graminis $\mathrm{f}$. sp. tritici under artificial conditions. Pages 292-332 In: The Cereal Rusts, Vol. 1. Origins, Specificity, Structure, and Physiology. W. R. Bushnell and A. P. Roelfs, eds. Academic Press, Orlando, FL.

15. Singh, R. P., Hodson, D. P., Jin, Y., HuertaEspino, J., Kinyua, M. G., Wanyera, R., Njau, P., and Ward, R. W. 2006. Current status, likely migration and strategies to mitigate the threat to wheat production from race Ug99 (TTKS) of stem rust pathogen. CAB Reviews: Perspectives in Agriculture, Veterinary Science, Nutrition and Natural Resources. 1. No. 054.

16. Smith, E. L., Schlehuber, A. M., Young, H. C., Jr., and Edwards, L. H. 1968. Registration of Agent wheat. Crop Sci. 8:511-512.

17. Stakman, E. C., Steward, D. M., and Loegering, W. Q. 1962. Identification of physiologic races of Puccinia graminis var. tritici. U. S. Dep. Agric. ARS E-617.

18. Szabo, L. J. 2007. Development of simple sequence repeat markers for the plant pathogenic rust fungus, Puccinia graminis. Mol. Ecol. Notes 7:92-94.

19. Wanyera, R., Kinyua, M. G., Jin, Y., and Singh, R. 2006. The spread of stem rust caused by Puccinia graminis $\mathrm{f}$. sp. tritici, with virulence on $\mathrm{Sr} 31$ in wheat in Eastern Africa. Plant Dis. 90:113. 